\title{
ULTRASONOGRAPHIC BIOMETRY OF SOFT TISSUES IN PATIENTS WITH GINGIVAL RECESSIONS. PRELIMINARY REPORT
}

\author{
Ingrid Różyło-Kalinowska', Jakub Kuryło², Stanisław Nowak², Magdalena Piskórz', Katarzyna Portka', \\ Magdalena Kozek \\ 'Department of Dental and Maxillofacial Radiology, Medical University of Lublin, Poland \\ ${ }^{2}$ Student Scientific Group in the Department of Dental and Maxillofacial Radiology, Medical University of Lublin, Poland
}

\begin{abstract}
INTRODUCTION: Ultrasound waves have been used in the imaging of oral soft tissues since the beginning of the 1960s. Since then, the possibilities of using ultrasound devices in dental diagnostics have significantly increased. The biometric ultrasonograph Pirop ${ }^{\circledR}$ is an example of a device used for non-invasive measurements of soft tissues.

ОвјестіVEs: The aim of the study is to compare the thickness of soft tissues around teeth with gingival recession and the same teeth on the contralateral side without gingival recession, assessed with the use of an ultrasound Pirop $^{\circledR}$ device.

MATERIAL AND METHODS: The material consisted of 15 women in the age range $22-27$ years, in whom were diagnosed 18 unilateral gingival recessions at the incisors, canines, and premolars. Before the examination, the patients answer the questions included in questionnaire about the following: history of dental treatment, coexisting systemic diseases, medicaments, and the presence of addictions. At each tooth with gingival recession three measurement points were deterred to determine the thickness of the marginal and attached gingiva and the mucogingival junction. All measurements were made individually by two researchers.

RESULTS: Most of the gingival recession was found in the second quadrant (44\%), and the most commonly affected teeth were 23 and 24 (about 40\%). In the area of the incisors, canines, and premolars, the most common gingival recessions occurred in premolars (50\%). The results of the measurements carried out on the recessive teeth were: for the gingival margin $-0.36-2.29 \mathrm{~mm}$, for the attached gingiva $-0.35-2.97 \mathrm{~mm}$, and for the mucogingival junction $-0.36-2.68 \mathrm{~mm}$. For both researchers and for every measurement point, soft tissues were thinner at teeth with gingival recessions by more than $50 \%$.

Conclusions: The Pirop ${ }^{\circledR}$ ultrasonograph is proper, non-invasive device used to measure the thickness of soft tissues. In our study, the thickness of the mucosa around the teeth affected by the gingival recession was lower in comparison to the sound tissues on the contralateral side in the majority of the examined patients.
\end{abstract}

KEY wORDs: Pirop ${ }^{\circledR}$, ultrasonograph, measurements of soft tissues, gingival recession.

J Stoma 2019; 72, 3: 106-111

DOI: https://doi.org/10.5114/jos.2019.87523

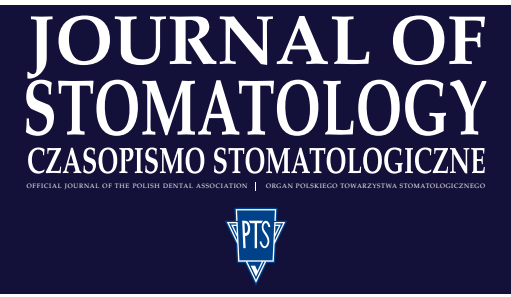

AdDRESS FOR CORRESPONDENCE: Dr. Magdalena Kozek, Department of Dental and Maxillofacial Radiology, Medical University of Lublin, Poland, e-mail: kozek.magdalena@gmail.com

ReCeIved: 20.03.2019 • ACCEPTED: 04.07.2019 • Published: 08.08.2019 


\section{INTRODUCTION}

Ultrasonography is an imaging method that uses sound wave divergence in the human body. Ultrasounds are sounds with frequencies above $20,000 \mathrm{~Hz}$. Waves in the range of 12 to $50 \mathrm{MHz}$ are usually used in dentistry $[16,23]$. The source of acoustic waves is a probe containing a piezoelectric transducer, which simultaneously acts as a transmitter and detector of acoustic signals. The returning signal is picked up by the probe as mechanical vibration of the reflected wave from the examined object, the so-called echo [13].

Ultrasound waves have been used in the imaging of oral soft tissues since the beginning of the 1960s [1]. Since then, the possibilities of using ultrasound devices in dental diagnostics have significantly increased. The Pirop ${ }^{\circledR}$ biometric ultrasonograph is an example of a device (EchoSon S.A., Puławy, Poland) used for non-invasive measurements of soft tissues (Figure 1). Various areas of the oral mucosa can be assessed by manipulating a probe of $1.7 \mathrm{~mm}$ in diameter and $20 \mathrm{MHz}$ frequency. The time taken by ultrasound waves, moving at a known and constant speed $(1540 \mathrm{~m} / \mathrm{s})$ to come back to the probe after perpendicular reflection from the object with a more dense architectural structure is used to calculate the travelled distance, which corresponds to the soft tissue thickness at the examined point. In each region of interest (ROI) soft tissue thickness is measured 10 times, and the average value together with standard deviation are recorded. Accuracy of measurements is estimated at $0.01 \mathrm{~mm}$, and the measurement depth range is $0.2-6.0 \mathrm{~mm}$. Calculated value can be printed or saved in a storage medium and transferred to a virtual patient's card [2].

The periodontal phenotype is determined by the three-dimensional gingival volume and the thickness of the bone morphotype - the thickness of the buccal bone plate. The phenotype can be modified, but the genotype cannot be changed. Many authors use the term biotype [18]. We can distinguish two types of biotype: thick-flat and thin-scalloped $[14,15]$. In thin phenotype gingival recession often occurs [18].

Gingival recession is an apical shift of the gingival margin. It is correlated with clinical attachment loss and should be on all surfaces of the tooth - buccal, lingual, interproximal. Gingival recession may be caused by different conditions or pathologies [18].

The gingival margin covering the tooth without gingival recession is a line with a garlanded shape that corresponds to the tooth-tipped tooth neck [22]. The aetiology of gingival recessions may be different, and their occurrence is more prevalent in orthodontic patients with fixed appliances. It may also be related to congenital bone structure, shape, size, and location of the teeth, and the surrounding soft tissues, gingiva, and mucosa, as well as muscles. Functional conditions such as: mechanical trauma resulting from the incorrect technique of brushing teeth and iatrogenic injuries after dental treatment, are also important in aetiology of gingival recessions. Accumulation of dental plaque is also a contributing factor. Gingival recessions are more common in women and older patients [3]. Also, patients with inappropriate width of attached gingiva are prone to gingival recessions - narrow and thin gingiva $(<1 \mathrm{~mm})[9,21]$. It is also important that the improper oral hygiene on the exposed surface of the roots can predispose to caries development [24].

Measurement of soft tissue thickness using the Pirop ${ }^{\circledR}$ device can be used in studies of gingival recessions.

\section{OBJECTIVES}

The aim of the study is to compare the thickness of soft tissues around teeth with gingival recessions and contralateral teeth without gingival recessions assessed using the Pirop ${ }^{\circledR}$ ultrasound device.

\section{MATERIAL AND METHODS}

The material consisted of 15 women at the age between 22 and 27 years, in whom were diagnosed a total of 18 unilateral gingival recessions at the incisors, canines, and premolars (one patient had three unilateral gingival recessions, and another had two $)(n=18)$. Only patients with unilateral gingival recessions were classified to this group, to compare the morphology of proper soft tissues and soft tissues around the teeth with gingival recessions.

All patients signed an informed consent form, and the local Bioethical Committee approved the study design - KE-0254/242/2018. Before the examination, the patients filled out a questionnaire, which included questions such as: history of dental treatment - orthodontic, periodontal, or surgical treatment, pre-existing systemic diseases, medicaments, and the presence of addictions. After analysing the surveys carried out before the study, it was concluded that $80 \%$ of patients had completed

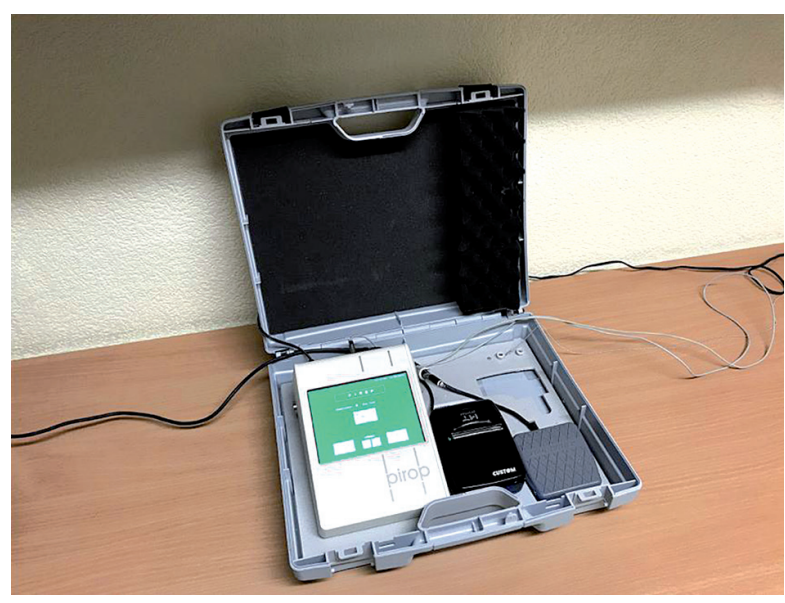

FIGURE 1. Biometric ultrasonograph Pirop ${ }^{\circledR}$ 


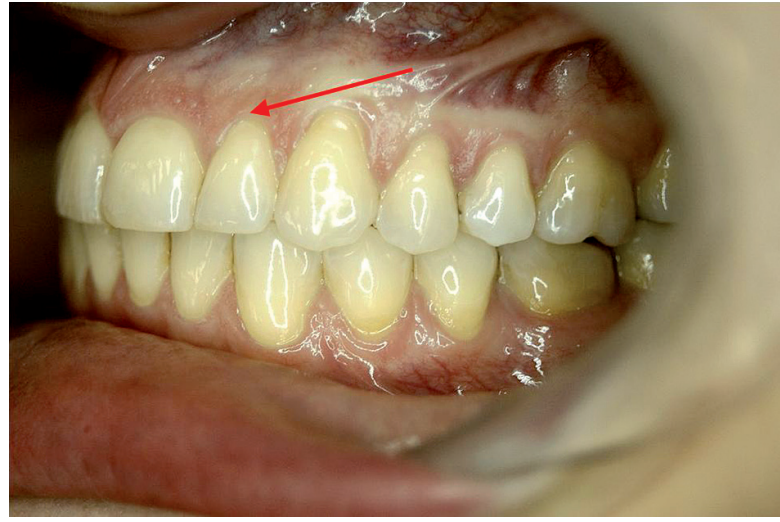

FIGURE 2. First measuring point - marginal gingiva

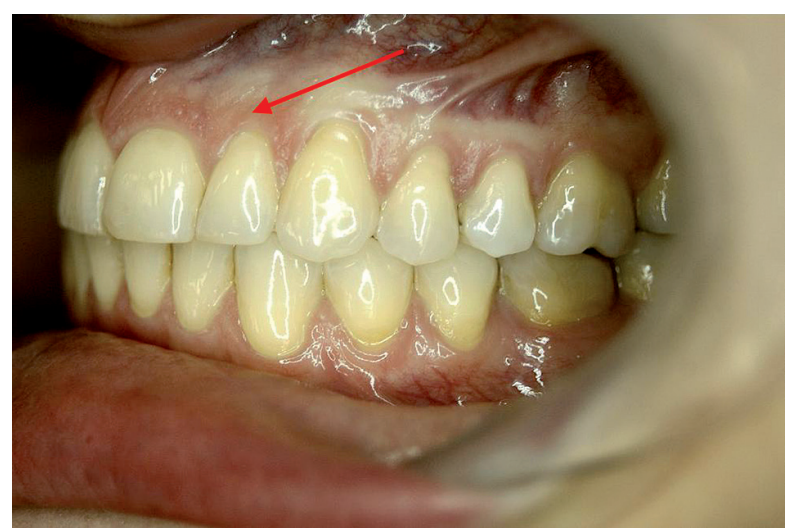

FIGURE 3. Second measuring point - attached gingiva

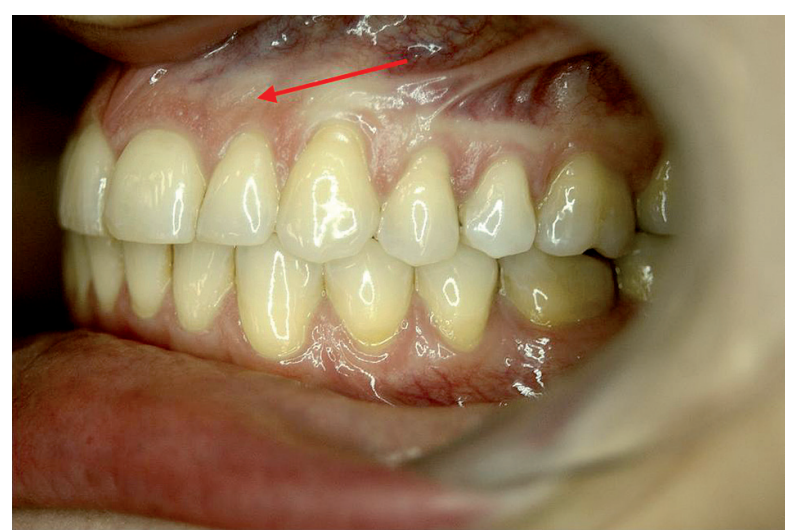

FIGURE 4. Third measuring point - mucogingival junction

orthodontic treatment in the past. Among the addictions, four respondents $(27 \%)$ reported smoking. Pregnant women were excluded from the examined group. Clinical examination revealed healthy periodontium in the assessed area in all patients. They had no visible features of inflammation of gingiva, i.e. redness, bleeding, or swelling.

At each tooth with gingival recession, three measurement points were determined to measure the thickness of the marginal gingiva, the attached gingiva, and the mucogingival junction. To determine the thickness of the gingiva in the first measuring point, the probe was positioned so that its edge adhered to the edge of the gingiva (Figure 2). The second measurement point was determined by placing the probe tip halfway up the attached gingiva (Figure 3). Measurements of mucosa thickness in the third measurement point were obtained by applying the probe to the surface of the mobile mucosa while remaining in contact with the mucogingival junction (Figure 4). The probe was applied to an external surface of the mucosa, without pressuring soft tissues. All measurements were made in the long axis of the tooth, on the line running through its centre, and the probe's front was directed at right angles to the surface of the alveolar bone covering the root of the tooth.

At each point, 10 measurements were obtained automatically, from which the average value was then calculated. In the event of discrepancies in measurements, the researchers repeated the test. To avoid the presence of air bubbles between the gingival surface and the probe, dental gel with chlorhexidine (Elugel) was used.

Each measurement was performed not only at the tooth with gingival recession but also at the contralateral tooth without gingival recession. This was due to the lack of standards of gingival thickness determined in the literature obtained with the use of the Pirop ${ }^{\circledR}$ ultrasonograph. To each tooth without gingival recession (18) three measurement points were determined in exactly the same way as for the tooth with gingival recession, to mark the thickness of the marginal gingiva, the attached gingiva, and the mucogingival junction.

All measurements were carried out by two researchers with similar experience during one session (J.K and S.N) after previous clinical examination of the patient and consensus establishment of measuring points, to minimise the risk of divergences. The measurements will be repeated by the investigators in the further stages of the research to determine interobserver agreement.

The results presented in this paper results are preliminary ones, and according to the number of patients only basic descriptive statistical tools were used.

\section{RESULTS}

In the surveyed group, more gingival recessions were found on the left (73\%) than on the right side (28\%). Most of the gingival recessions were found in the second quadrant (44\%), and the most commonly affected teeth were 23 and 24 (about 40\%). In the area of the incisors, canines, and premolars, the most gingival recessions occurred in premolars (50\%), while the upper incisors did not reveal their presence.

The results of the measurements carried out at the teeth with gingival recession were: for the gingival margin - between 0.36 and $2.29 \mathrm{~mm}$, for the attached gingi$\mathrm{va}-0.35-2.97 \mathrm{~mm}$, and for the mucogingival junction $-0.36-2.68 \mathrm{~mm}$. 
For the first researcher at teeth, the average value of gingival margin thickness was $0.78 \mathrm{~mm}$, attached gingiva $0.59 \mathrm{~mm}$, and the mucogingival junction $0.77 \mathrm{~mm}$. The average values for the same points at the contralateral teeth were, respectively, $1.02 \mathrm{~mm}, 0.94 \mathrm{~mm}$, and $0.83 \mathrm{~mm}$. At all three points, the average soft tissue thickness was higher for the teeth without a confirmed gingival recession. For the second investigator, the mean values of soft tissue thickness in teeth with gingival recession were as follows: first point $0.93 \mathrm{~mm}$, second point $0.75 \mathrm{~mm}$, and third point $0.74 \mathrm{~mm}$. In the area of teeth with no gingival recessions recorded, the mean values for the same points were successively, $0.97 \mathrm{~mm}$, $0.87 \mathrm{~mm}$, and $0.82 \mathrm{~mm}$. Also, after the analysis of the results of mean values of soft tissue thickness made by the second researcher, it was found that they are higher for the teeth without gingival recession (Table 1).

After detailed analysis of the results obtained for the first researcher, the measurements of gingival margin in $78 \%$ of measurements were higher for teeth without gingival recession, as well as for attached gingiva, in $78 \%$ of measurements gingiva was thicker also for teeth without gingival recession, and for the mucogingival junction in $67 \%$ of measurements mucosa was thicker again for teeth without gingival recession. After the analysis of the results for the second researcher, it was found that $55 \%$ of results for the thickness of gingival margin were higher for teeth without gingival recession, in $61 \%$ of the measurements soft tissues was thicker for teeth without gingival recession, and $67 \%$ of measurements made at the mucogingival junction were higher also for teeth without gingival recession. This proves that for each researcher, for every measurement point, soft tissues around teeth were thinner at teeth with gingival recessions of more than 50\% (Table 2).

Comparing the mean values for both investigators, differences were observed, which may be affected by the pressure of the probe on the gingival surface, or the angle between the tip and the gingival surface.

\section{DISCUSSION}

In the past, in order to measure thickness of the soft tissues, invasive methods were commonly performed. The most widespread method was bone sounding (BS). To use this method, it was necessary to apply local anaesthesia and use an injection needle or endodontic instrument with a silicone stopper and probe to the bone level $[4,10]$. The second method was measurement with the use of a periodontal probe under a local anaesthesia. When the thickness was more than $1.5 \mathrm{~mm}$ the biotype was described as thick, and values less than $1.5 \mathrm{~mm}$ were described as thin biotype [21]. The main disadvantage of invasive methods was the effect of anaesthesia on soft tissues, which caused higher results. What is more, these methods were uncomfortable for patients.
Computed tomography was also used to assess the thickness of soft tissues, but due to high doses of radiation, the cost of examination, and limited accessibility it is not a recommended method [17].

Various ultrasonic devices were used in the past for determining the gingival biotype and diverse results of facial and palatal gingival biotypes were received. The differences were caused by the following factors: type of equipment, racial variation, patient's age, and different methodologies. The results of palatal gingival measurements were obtained by four independent researchers. All of them used different equipment. Rajpoot et al. [12] used a Biometric A - Scan ultrasound device and gained values between 1.55 and $1.98 \mathrm{~mm}$, whereas Uchida et al. [19], with the use of B-mode ultrasound device, found higher values, i.e. 1.92-2.38 mm. Similar values (2.2-2.8 mm/2.2-2.9 mm) were obtained by Kydd et al. [8] and Eger et al. [5], but they used different devices (A-mode/SDM Krup) [9].

Eger et al. [5] used an ultrasound device for determining the validity and reliability of gingival thickness, and they claimed that this device was excellent. Based on their examinations they found that GTH (gingival thickness) depends not on the shape and form of the tooth but mainly on the tooth type and the width of the gingiva.

This novel method has a lot of advantages. Mainly is non-invasive, atraumatic whilst performing, and there is no need to use local anaesthesia. The examination is absolutely painless and safe for both patient and doctor.

Thanks to the smallest available diameter of probe $(1.7 \mathrm{~mm})$, the measurements are very precise. The results are obtained immediately and are rapidly available

TABLE 1. Mean values of measurements at 3 points by two researchers

\begin{tabular}{|c|c|c|c|c|}
\hline & \multicolumn{2}{|c|}{ I researcher } & \multicolumn{2}{|c|}{ II researcher } \\
\hline & $\begin{array}{l}\text { With } \\
\text { recession }\end{array}$ & $\begin{array}{l}\text { Without } \\
\text { recession }\end{array}$ & $\begin{array}{l}\text { With } \\
\text { recession }\end{array}$ & $\begin{array}{l}\text { Without } \\
\text { recession }\end{array}$ \\
\hline Marginal gingiva & $0.78 \mathrm{~mm}$ & $1.02 \mathrm{~mm}$ & $0.93 \mathrm{~mm}$ & $0.97 \mathrm{~mm}$ \\
\hline Attached gingiva & $0.59 \mathrm{~mm}$ & $0.94 \mathrm{~mm}$ & $0.75 \mathrm{~mm}$ & $0.87 \mathrm{~mm}$ \\
\hline $\begin{array}{l}\text { Mucogingival } \\
\text { junction }\end{array}$ & $0.77 \mathrm{~mm}$ & $0.83 \mathrm{~mm}$ & $0.74 \mathrm{~mm}$ & $0.78 \mathrm{~mm}$ \\
\hline
\end{tabular}

TABLE 2. Comparison between researchers showing how many per cent results were higher in teeth without recession

\begin{tabular}{|l|c|c|}
\hline \multicolumn{1}{|c|}{ I researcher } & II researcher \\
\hline Marginal gingiva & $78 \%$ & $55 \%$ \\
\hline Attached gingiva & $78 \%$ & $61 \%$ \\
\hline Mucogingival junction & $67 \%$ & $67 \%$ \\
\hline
\end{tabular}


on a screen. Finally, a positive aspect is also the low cost of examination.

Unfortunately, the ultrasound method also has some disadvantages. There are some difficulties in determining palatal biotypes caused by various anatomical shapes of the alveolar process. The operator has to learn how to properly use the device, because it is tremendously sensitive. The pressure during probing has to be less than $25 \mathrm{~g}$. What is more, the probe must be placed perpendicular to the root surface, otherwise the examination will be painful and the results will not be reliable. The high cost of equipment can be an objective.

So far, a new ultrasonic system, the Pirop ${ }^{\circledR}$ biometer, was used for assessing the gingival thickness (GTH) in specific locations established by Bednarz et al. [2, 3]. It was possible to determine these points because the diameter of the probe in the Pirop ${ }^{\circledR}$ device is the smallest of all available in the market. Previous diameters of probes were about $4 \mathrm{~mm}$, and hence the measurements were not as precise as in the Pirop ${ }^{\circledR}$ device.

Pirop ${ }^{\circledR}$ was also used for checking the repeatability of gingival thickness measurements, and the authors claimed that the best repeatability was obtained in the supracrestal region that is $1 \mathrm{~mm}$ apical than CAL and free GT - $1 \mathrm{~mm}$ coronal than CAL [3].

Furthermore, Pirop ${ }^{\circledR}$ was used by Puzio et al. [11] to evaluate the thickness of keratinised gingiva around implants before and three months after augmentation of gingiva by means of connective tissue graft and collagen matrix. It was found that higher values were recorded after augmentation surgery with connective tissue graft.

Bednarz et al. [3] compared the method of invasive and non-invasive examination of gingival thickness using the Pirop ${ }^{\circledR}$ device and bone sounding method using an endodontic tool with a stopper. They noticed that the results obtained using the invasive method were similar, but they were significantly different and were higher than using the non-invasive method.

Furtak et al. [6] claimed that their non-invasive method (with the use of Pirop ${ }^{\circledR}$ ) is useful because they gained $8.4 \%$ repeatability and reproducibility of measurements.

Determination of gingival biotypes is crucial in all branches of dentistry, not only in periodontal plastic surgery and implant therapy but also in orthodontics and prosthetics; therefore, we believe that this modern device is useful, if certain conditions are fulfilled. Mainly these are the repeatability of one's own measurements and performing measurements using pressure on tissues less than $25 \mathrm{~g}$.

\section{CONCLUSIONS}

The thickness of the mucosa at the site of teeth affected by gingival recession was lower than at the contra- lateral teeth without recessive features of gingival recession, in the majority of examined patients. The Pirop ${ }^{\circledR}$ ultrasound unit seems to be a reliable, non-invasive device that can be used in measurements of soft tissue thickness.

\section{CONFLICT OF INTEREST}

The authors declare no potential conflicts of interest with respect to the research, authorship, and/or publication of this article.

\section{References}

1. Baum G, Greenwood I, Slawski S, Smirnow R. Observation of internal structures of teeth by ultrasonography. Science 1963; 139: 495-496.

2. Bednarz W. Nowe możliwości diagnostyczne tkanek przyzębia przy zastosowaniu biometrii ultradźwiękowej. e-Dentico 2015; 1: 8-21.

3. Bednarz W, Zielińska A. Zastosowanie biometru ultradźwiękowego w badaniu grubości tkanek miękkich przyzębia i porównanie jego dokładności pomiarowej z metodą „bone sounding”. Dent Med Probl 2011; 48: 481-489.

4. da Silva RC, Joly JC, de Lima AF, Tatakis DN. Root coverage using the coronally positioned flap with or without a subepithelial connective tissue graft. J Periodontol 2004; 75: 413-419.

5. Eger T, Müller HP, Heinecke A. Ultrasonic determination of gingival thickness. Subject variation and influence of tooth type and clinical features. J Clin Periodontol 1996; 23: 839-845.

6. Furtak A, Leszczyńska E, Sender-Janeczek A, Bednarz W. The repeatability and reproducibility of gingival thickness measurement with an ultrasonic device. Dent Med Probl 2018; 255: 281-288.

7. Górska R, Konopka T. Periodontologia współczesna. Med Tour Press International Sp. z o.o., 2013; 383-407.

8. Kydd WL, Daly CH, Wheeler JB III. The thickness measurement of masticatory mucosa in vivo. Int Dent J 1971; 21: 430-441.

9. Muller HP. Periodontologia. Lublin: Czelej, 2003; 94-96.

10. Nugala B, Kumar BS, Sahitya S, Krishna PM. Biologic width and its importance in periodontal and restorative dentistry. J Conserv Dent 2012; 15: 12-17.

11. Puzio M, Błaszczyszyn A, Hadzik J, Dominiak M. Ultrasound assessment of soft tissue augmentation around implants in the aesthetic zone using a connective tissue graft and xenogeneic collagen matrix - 1-year randomised follow-up. Ann Anat 2018; 217: 129-141.

12. Rajpoot N, Nayak A, Nayak R, Bankur PK. Evaluation of variation in the palatal gingival biotypes using an ultrasound device. J Clin Diagn Res 2015; 9: ZC56-ZC60.

13. Różyło-Kalinowska I, Różyło TK. Współczesna radiologia stomatologiczna. Lublin: Czelej, 2015; 52.

14. Seibert J, Lindhe J. Aesthetics and periodontal therapy. In: Lindhe J (ed.). Clinical Periodontology. $3^{\text {th }}$ ed. Copenhagen: Munksgaard, 1997; 647-681.

15. Serino G, Wennstrom JL, LIndhe J, Eneroth L. The prevalence and distribution of gingival recession in subjects with a high standard of oral hygiene. J Clin Periodontol 1994; 21: 57-63.

16. Slak B, Daabous A, Bednarz W, Strumban E, Maev RG. Assessment of gingival thickness using an ultrasonic dental system prototype: a comparison to traditional methods. Ann Anat 2015; 199: 98-103.

17. Song JE, Um YJ, Kim CS, et al. Thickness of posterior palatal masticatory mucosa: the use of computerized tomography. J Periodontol 2008; 79: 406-412.

18. Jepsen S, Caton JG, Albandar JM, et al. Periodontal manifestations of systemic diseases and developmental and acquired conditions: 
Consensus report of workgroup 3 of the 2017 World Workshop on the Classification of Periodontal and Peri-Implant Diseases and Conditions. J Clin Periodontol 2018; 45 Suppl 20: S219-S229.

19. Uchida H, Kobayashi K, Nagao M. Measurement in vivo of masticatory mucosal thickness with $20 \mathrm{MHz} B$ mode ultrasonic diagnostic equipment. J Dent Res 1989; 68: 95-100.

20. Vandana KL, Savitha B. Thickness of gingiva in association with age, gender and dental arch location. J Clin Periodontol 2005; 32: 828-830.

21. Hall WB. Podejmowanie decyzji w periodontologii. Jańczuk Z (tłum. pod red.). Wyd. D.W. Publishing Co., 1993; 98.

22. Wennstrom JL. Mucogingival surgery. In: Lang NP, Karring T (eds.). Proceedings of the $1^{\text {st }}$ European Workshop on Periodontology. Berlin: Quintessence, 1994; 193-209.

23. White SC. Radiologia stomatologiczna. $1^{\text {st }}$ ed. Lublin: Czelej, 2002; 254.

24. Zucchelli G, Mounssif I. Periodontal plastic surgery. Periodontology $20002015 ; 68: 333-368$. 